\title{
Effects of 8-prenylnaringenin on the hypothalamo-pituitary-uterine axis in rats after 3-month treatment
}

\author{
J Christoffel, G Rimoldi and W Wuttke
}

Division of Clinical and Experimental Endocrinology, Department of Obstetrics and Gynecology, University of Göttingen, Robert-Koch-Str 40, 37099 Göttingen, Germany

(Requests for offprints should be addressed to W Wuttke; Email: ufkendo@med.uni-goettingen.de)

\begin{abstract}
Phytoestrogens are increasingly consumed in artificially high doses as herbal preparations and nutritional supplements. The flavanone 8-prenylnaringenin $(8 \mathrm{PN})$ is a potent phytoestrogen, but its benefits and risks after long-term application are poorly identified. Therefore, we tested two doses of 8PN and $17 \beta$-estradiol-3-benzoate (E2B) (effective doses: 6.8 and $68.4 \mathrm{mg} / \mathrm{kg}$ body weight $(\mathrm{BW})$ of $8 \mathrm{PN}$, and $0 \cdot 17$ and $0 \cdot 7 \mathrm{mg} / \mathrm{kg} \mathrm{BW}$ of $17 \beta$ estradiol (E2)) and compared their effects on uterine weight, pituitary hormones (LH, FSH and prolactin) and the expression of estrogen-regulated genes and of estrogen receptor (ER) $\alpha$ and ER $\beta$ in the hypothalamus, pituitary and uterus. Both doses of E2 and the high dose of 8PN suppressed serum LH and FSH, and stimulated serum prolactin levels, uterine weight, and progesterone receptor, insulin-like growth factor I and complement protein C3 mRNA transcripts. In the preoptic and the mediobasal areas of the hypothalamus, all treatments had negligible
\end{abstract}

effects on ER $\alpha$ and $E R \beta$ and gonadotropin-releasing hormone $(\mathrm{GnRH})$ receptor gene expression, while ER $\beta$ and $\mathrm{GnRH}$ receptor transcripts in the anterior pituitary were reduced under both E2 doses and the high 8PN dose. The mRNA concentrations of the LH $\alpha$ and $-\beta$ subunits in the pituitary were suppressed by E2 and 8PN. In summary, $8 \mathrm{PN}$ had very similar though milder effects than E2 on all tested parameters. Inhibition of climacteric complaints by E2 takes place in the hypothalamus, where it inhibits the overactive GnRH pulse generator. Hence, $8 \mathrm{PN}$ may be used to inhibit climacteric symptoms effectively. Human pharmacologic studies will show whether the stimulatory effect on the uterus that was found in the present animal model would require the concomitant administration of progestins to prevent endometrial overstimulation.

Journal of Endocrinology (2006) 188, 397-405

\section{Introduction}

The flavanone 8-prenylnaringenin (8PN) was identified as a potent phytoestrogen in a Thai crude drug (Kitaoka et al. 1998) and as an estrogenic compound in female hops cones (Milligan et al. 1999). 8PN is therefore found in beer, in which hops is used as a flavoring and aromatic agent, although the content varies considerably depending on the hop variety used for brewing. The recently published data on mammary cancer- and arteriosclerosisstimulating effects associated with long-term hormone replacement therapy of postmenopausal women (Rossouw et al. 2002) boosted research to establish alternatives to this treatment. Plant-derived phytoestrogens may be such an alternative, and several compounds, including 8PN, have been shown to have estrogenic effects (Milligan et al. 2000, 2002, Zierau et al. 2002). In recent years, hops has increasingly appeared as a component of herbal preparations for 'bust enhancement' that are mainly available via the Internet (Fugh-Berman 2003), and 8PN proved to be the main estrogenic compound of a dietary supplement for oral use (Coldham \& Sauer 2001). Consumers of these products will be prone to unlimited use. Biologic research with $8 \mathrm{PN}$ started only recently, and it was shown that it binds to both estrogen receptors (ER); ER $\alpha$ and ER $\beta$. In receptor-binding studies and in transfected yeast cells, it had the strongest ER $\alpha$ activity detected for a phytoestrogen so far (Bovee et al. 2004); the $\mathrm{ED}_{50}$ to displace estradiol-17 $\beta$ (E2) from $E R \alpha$ and $E R \beta$ was close to $10^{-5} \mathrm{M}$, and $8 \mathrm{PN}$ caused transactivation in a receptor transfected yeast screening assay at $\mathrm{nM}$ concentrations (Milligan et al. 2000, 2002). In vitro it lacked androgenic and progestogenic activities (Milligan et al. 2000), but mild antiandrogenic activity was demonstrated (Zierau et al. 2003). 8PN also inhibits angiogenesis in vitro and in vivo (Pepper et al. 2004). In studies for its estrogenic activity in vivo, a dose of $10 \mathrm{mg} / \mathrm{kg}$ body weight $(\mathrm{BW}) /$ day given once or for 3 days caused uterotrophic response, and a longer s.c. application of 2 weeks $(30 \mathrm{mg} / \mathrm{kg}$ per day) had positive effects on bone density measured by 
dual energy X-ray absorptiometry and urinary bone turnover markers (Miyamoto et al. 1998, Diel et al. 2004). In ovariectomized (ovx) mice, $0.5 \mu \mathrm{g} 8 \mathrm{PN} / \mathrm{g}$ food did not evoke uterotrophic response (Coldham \& Sauer 2001), whereas s.c. application of $10 \mathrm{mg} / \mathrm{kg}$ per day to ovx rats stimulated uterine weight (Diel et al. 2004).

Due to the estrogenic potency of 8PN, safety questions arise concerning unrestricted long-term use of freely accessible herbal preparations, and there is a need to study long-term application to evaluate possible benefits and risks.

Therefore, the model of the ovx rat was chosen, which is a widely used and accepted model to study estrogenic activities. A treatment time of 3 months was selected to determine whether the endocrine regulation of hypothalamo-pituitary-gonadal (HPG) axis is altered under constant oral application conditions, which is the consumer's preferred administration route. The so-called negative feedback effect of E2 on pituitary gonadotropin (luteinizing hormone (LH) and follicle-stimulating hormone $(\mathrm{FSH})$ ) and the stimulatory effect on prolactin release are exerted in the hypothalamus as well as in the pituitary. Hence, both structures express ER $\alpha$ and ER $\beta$. The release of the pituitary gonatrotropins is stimulated by hypothalamic gonadotropin-releasing hormone $(\mathrm{GnRH})$, of which the receptors in the hypothalamus and the pituitary may also be modulated by E2 and estrogenic compounds. Two doses of both E2 and 8PN were given to study effects on pituitary hormones and the gene-expression profile of estrogen-regulated genes in hypothalamus, pituitary and uterus.

E2 is known to stimulate uterine weight by increased production of insulin-like growth factor I (IGF-I). Furthermore, it stimulates the expression of the progesterone receptor (PR) and of the complement protein $\mathrm{C} 3$, which is the most sensitive marker of estrogenic effects in the uterus (Seidlova-Wuttke et al. 2003a). Whether E2 alters gene expression of ER $\alpha$ and ER $\beta$ in the hypothalamus and pituitary is disputed (Shupnik 1996, Shughrue et al. 2002, Petersen et al. 2003) and will therefore also be studied and the observed effects of E2 compared with those exerted by $8 \mathrm{PN}$.

Most GnRH neurons in the rat hypothalamus are located in the preoptic area (POA), and their axons terminate at the portal vessels of the median eminence of the mediobasal hypothalamus (MBH) (Gore 2002). The GnRH neurons signal their activity to neighboring neurons in both hypothalamic structures, as GnRH receptors are found in the POA and the MBH (Piva et al. 2004).

In the pituitary, LH and FSH are synthesized by the gonadotrophs. These two hormones consist of an unspecific $\alpha$-subunit and an LH-specific $\beta$-subunit, of which the mRNA expression may also be regulated by E2 and other estrogenic compounds. Hence, a number of estrogen-regulated parameters in the hypothalamus, pituitary and uterus may serve to study putative estrogenic effects of 8PN and to compare them with those of E2.
Assuming a bioavailability of $10 \%$, which was reported after oral application of isoflavones to rats (Mallis et al. 2003), we chose two doses of 8PN to study the effects in the hypothalamo-pituitary-uterine axis and to compare them with a low and high dose of E2. E2 was administered as $17 \beta$-estradiol-3-benzoate (E2B) to improve the low oral bioavailability of E2 (Schleicher et al. 1998), and doses were chosen according to experience and standard protocol in the laboratory (Seidlova-Wuttke et al. 2003b, 2004a).

\section{Materials and Methods}

\section{Chemicals}

8PN was kindly supplied by Schering AG, Berlin, Germany. The synthetic product was a racemate of both naturally occurring enantiomeres $2 S(-) 8 \mathrm{PN}$ and $2 R(+) 8 \mathrm{PN}$ (>99\% purity certified by NMR). E2B ( $98.5 \%$ purity) was purchased from Sigma.

\section{Animals}

Experiments were performed with rats bred in our own animal facilities. Sprague-Dawley rats for the parental generation were obtained from Fa. Winkelmann (Borchen, Germany) and fed soy-free food for at least 3 weeks before they were mated. Their pups were raised and kept under soy-free conditions, and the female offspring entered the experiment. The animals were housed at $23{ }^{\circ} \mathrm{C}$ and $55 \%$ relative humidity in a $12-\mathrm{h}$ light:dark cycle, and were allowed free access to chow and water. With legal approval (permission no. 509·42502/ 01-36.03, district authorities of Braunschweig), the experiments were performed according to the German animal welfare regulations.

\section{Study design}

Animals were ovx at the age of 4 months. Treatment started immediately afterward by switching them to the $8 \mathrm{PN}$ - or E2B-supplemented chow $(n=10-12)$ and lasted 3 months. Substances were given orally to imitate the regular route of human ingestion, including resorption restrictions, influence of intestinal flora and first-pass metabolism in the liver. The chow was provided by Ssniff Special Diet, Soest, Germany. Regular diet was the soy-free formulation (Ssniff SM R/M, $10 \mathrm{~mm}$ ), in which soy proteins are replaced by potato proteins. The supplemented chow was prepared by mixing the test substances with this formulation to homogeneity before the process of pelleting. Concentrations of the two doses of E2B in the chow were 4.3 and $17.3 \mu \mathrm{g} / \mathrm{g}$, and of 8 PN 0.126 and $1.26 \mathrm{mg} / \mathrm{g}$ food respectively. All batches were prepared 1 week prior to the start of the experiment. During treatment, the development of body weight (BW), and 
food and water intake were surveyed. On the basis of ingested food, it was calculated after termination of the experiments that the animals received daily low and high doses of $8 \mathrm{PN}$ of 6.8 and $68.4 \mathrm{mg} / \mathrm{kg} \mathrm{BW}$, and of E2B of 0.17 and $0.7 \mathrm{mg} / \mathrm{kg} \mathrm{BW}$ (values calculated as free E2).

At the end of treatment, animals were killed by decapitation under light $\mathrm{CO}_{2}$ anesthesia. Trunk blood was collected and wet weight of uterus was determined. Besides the uterus, a number of organs, including brain and pituitary, were obtained. Organ specimens were immediately frozen in liquid nitrogen and stored at $-70{ }^{\circ} \mathrm{C}$.

\section{Serum analysis}

The blood samples were centrifuged $(3000 \mathrm{~g}, 20 \mathrm{~min})$ and the serum stored at $-20{ }^{\circ} \mathrm{C}$ for further analysis. $\mathrm{LH}, \mathrm{FSH}$, and prolactin were measured by specific RIA supplied by the National Hormone and Pituitary Program of the NIH (Dr A F Parlow, Harbor General Hospital, Torrance, CA, USA), as described previously (Roth et al. 2001b). Serum E2 was assayed with a commercially available kit (Estradiol $3^{\text {rd }}$ Generation; DSL, Sinsheim, Germany). To recover 8PN from serum in detectable amounts for HPLC-UV, enzymatic hydrolysis of potential metabolites was performed before serum extraction. A volume of $500 \mu \mathrm{l}$ serum was extended with $500 \mu \mathrm{NH}$ acetate buffer $(\mathrm{pH}$ $5 \cdot 0$ ) containing $1 \mathrm{mg} \beta$-glucuronidase (Helix Pomatia $\beta$-Glucuronidase Type H1; Sigma) and incubated overnight at $37^{\circ} \mathrm{C}$. The Strata $\mathrm{X}$ solid-phase extraction method with a polymeric sorbent was used. Columns of a $60 \mathrm{mg}$ bed mass $/ 3 \mathrm{ml}$ washing and elution volume (8BS100-UBJ, Phenomenex) were used according to the standard protocol. Methanol was substituted for ethanol, since EtOH was used for food analysis.

The eluted volume was evaporated to dryness in a Speedvac, 4-methyl-umbelliferone (4 MU) serving as an internal STD of the following reconstitution. Analytes were reconstituted with $100 \mu \mathrm{EtOH} 100 \%$, rinsing the interior of the glass tube and vortexing well. Then the samples were transferred to HPLC vials with $300 \mu \mathrm{l}$ microinserts, using a $1 \mathrm{ml}$ syringe and filtering through a PVDF membrane $0.45 \mu \mathrm{m} / 4 \mathrm{~mm}$ filter to remove remaining protein pollutants. An injection volume of $20 \mu \mathrm{l}$ was chromatographed over a NC 2504.6 mm HypersilODS 5.0 $\mu \mathrm{m}$ column (Bischoff, Leonberg, Germany), the retention time for $8 \mathrm{PN}$ being $13.1 \mathrm{~min}$. Total serum levels of 8PN after hydrolization were calculated on the basis of a standard curve utilizing serum spiked with $8 \mathrm{PN}$.

\section{$R T-P C R$}

Gene expression was determined by RT-PCR: GnRH in punches of the POA of the hypothalamus; GnRH receptor in the $\mathrm{MBH}$; gonadotropin $\alpha$ - and $\beta$-subunits in pituitary;
IGF-I, C3 and PR in uterus; and $\mathrm{ER} \alpha$ and $\mathrm{ER} \beta$ in all except POA.

Extraction of total RNA from the organs or micropunches of the POA of the hypothalamus and the protocol of the real-time PCR were described in detail previously (Roth et al. 2001a, Seidlova-Wuttke et al. 2003c). The reactions were run on an ABI Prism 7700 Sequence Detection System (TaqMan; PE Applied Biosystems, Foster City, CA, USA). The primers and probes were synthesized according to published validated systems: ER $\alpha$ and ER $\beta$, IGF-I, C3 and PR (Seidlova-Wuttke et al. 2003c); GnRH and its receptor (Roth et al. 2001b). Oligonucleotides were purchased from Eurogentec (Seraing, Belgium).

Additional TaqMan-systems (FAM =6-carboxy-fluorescein, TAMRA=6-carboxy-tetramethyl-rhodamine) were as follows:

Rat LH $\alpha$-subunit=gonadotropin $\alpha$-subunit (Godine et al. 1982)

Forward primer: 5'-TCTTGGACCTTGCGGGA GT-3'

Reverse primer: 5'-GGTGCCCCCATCTATCAG TG-3'

TaqMan-Probe: 5'FAM-TGCCCTGGAGAAGCAAC AGCCCAT-TAMRA3'

Rat $L H \beta$-subunit= gonadotropin $\beta$-subunit (Chin et al. 1983)

Forward primer: $5^{\prime}$-ACCTTCACCACCAGCATCT GT-3'

Reverse primer: 5'-AGCTCACGGTAGGTGCACA CT-3'

TaqMan-Probe: 5'FAM-CTGCCTTGCCTCCCGT GCCTCA-TAMRA3'

\section{Statistics}

In the present study, relative changes of mRNA levels were analyzed by comparison of the control and treatment groups. Based on the $C_{t}$ values of the PCR reactions measured in the control group, an average expression level of the analyzed target gene was calculated from the standard curve, which was set at $100 \%$. Individual $C_{t}$ values in the treatment groups were transformed in relation to this average value of the control group.

Data are presented as means \pm S.E.M. Significant differences between control and treatment groups were analyzed by multiple $t$-test comparison (Prism; GraphPad, San Diego, CA, USA). P values of $<0.05$ were considered significant.

\section{Results}

Serum E2 levels in ovx control animals were mostly undetectable, while the two E2B doses gave serum 
(a)

\section{BODYWEIGHT}

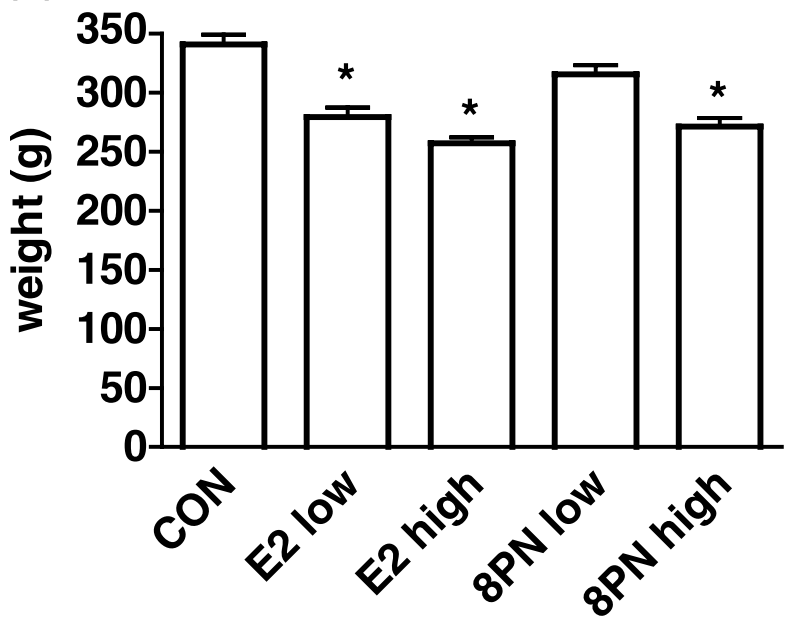

(b)

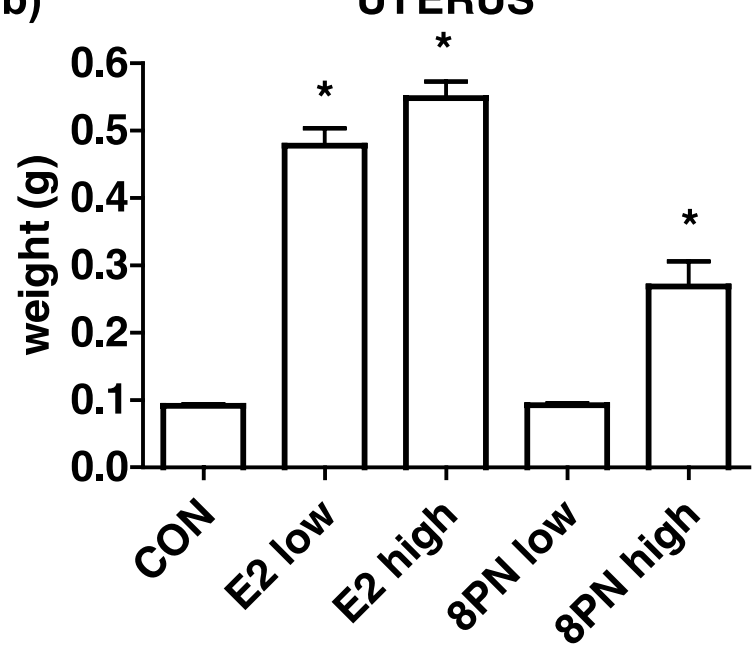

Figure 1 Effects of E2 and 8PN (both low and high dose) on body weight (a) and wet weight of uteri (b). Note the significant estrogenic effect of the high dose of $8 \mathrm{PN}$. ${ }^{*} P<0.05$ vs control. $n=10-12$.

concentrations of $149 \cdot 04 \pm 20 \cdot 61$ and $566 \cdot 84 \pm 55 \cdot 32 \mathrm{pM}$ respectively. Concentrations of $8 \mathrm{PN}$ after hydrolization of conjugates in the serum of the animals treated with the low or high dose were 14.46 \pm 1.95 and 109.80 \pm $23.79 \mu \mathrm{M}$ respectively.

Body and uterine weights of the animals are depicted in Fig. 1. The treatment with both doses of E2B and the higher dose of $8 \mathrm{PN}$ resulted in significantly reduced body weight (Fig. 1a), whereas uterine wet weight in the two E2B groups was significantly higher than in ovx animals, and the high dose of 8PN stimulated uterine weight significantly (Fig. 1b). However, the 8PN low dose had no effect on uterine weight. The effects of the treatments on uterine mRNA transcripts of ER $\alpha$ (Fig. 2a), ER $\beta$ (Fig. 2b), PR (Fig. 2c), IGF-I (Fig. 2d) and C3 (Fig. 2e) indicate an effect of $8 \mathrm{PN}$ at the high dose which was comparable to the effects exerted by the low dose of E2B.

Serum LH levels were significantly reduced by E2B and the higher dose of $8 \mathrm{PN}$ (Fig. 3a). The suppressive effects of E2B and 8PN on serum FSH achieved significance only for the higher E2B dose (Fig. 3b). Serum prolactin levels were significantly increased by the high dose of E2B and 8PN (Fig. 3c). This negative feedback effect of E2B and $8 \mathrm{PN}$ on the pituitary gonadotropins was reflected also in the expression of the LH $\alpha$ - and $\beta$-subunits and of the GnRH receptor mRNA transcripts, which were significantly reduced under both doses of E2B and the higher dose of 8PN (Fig. 4a, b and e). While ER $\alpha$ transcripts (Fig. 4c) in the pituitary were not affected by E2B or 8PN, both compounds at the higher dose reduced ER $\beta$ mRNA transcripts significantly (Fig. 4d).

In the POA and $\mathrm{MBH}, \mathrm{E} 2 \mathrm{~B}$ and $8 \mathrm{PN}$ had no significant effect on ER $\alpha$ and ER $\beta$ mRNA transcripts (Table 1). $\mathrm{GnRH}$ gene expression in the POA and GnRH receptor transcripts in the $\mathrm{MBH}$ also remained, statistically, unaffected by all treatments, although in the POA the amount of ER $\alpha$ was doubled and in GnRH mRNA transcripts it was tripled.

\section{Discussion}

The negative feedback of E2 involves neurotransmitters which dampen the activity of the hypothalamic GnRH pulse generator and thereby serum LH levels. After ovx or in postmenopausal women, the lack of estrogen causes changed release of these neurotransmitters (Jarry et al. 1986, 1990) and thereby overactivity of the pulse generator. The neurotransmitters involved in generating $\mathrm{GnRH}$ pulses spill over into neighboring neurons that regulate temperature and heart beat rate (Tataryn et al. 1979, Gambone et al. 1984), and this induces hot flushes and the associated tachycardiac attacks. Therefore, LH suppression caused by estrogenic substances alleviates these complaints. High but not low doses of $8 \mathrm{PN}$ reduced $\mathrm{LH}$ in the long-term treatment as strongly as the low dose of E2B. The ability of $8 \mathrm{PN}$ in a high dose to diminish LH release after 3-month treatment suggests that long-term intake could improve hot flushes in menopausal women. On the other hand, the high dose of $8 \mathrm{PN}$ increased uterine weight after long-term exposure, although much less than E2B. Uterotrophic effects are undesirable since they stimulate endometrial hyperplasia and the risk of development of endometrial cancer (Feeley \& Wells 2001). Therefore, any treatment of postmenopausal women with estrogen at doses that stimulate endometrial proliferation must be accompanied by interval or continuous treatment with progestin, which reduces the cancer risk (Lethaby et al. 2004). At the low dose, 8PN was devoid of 
(a)

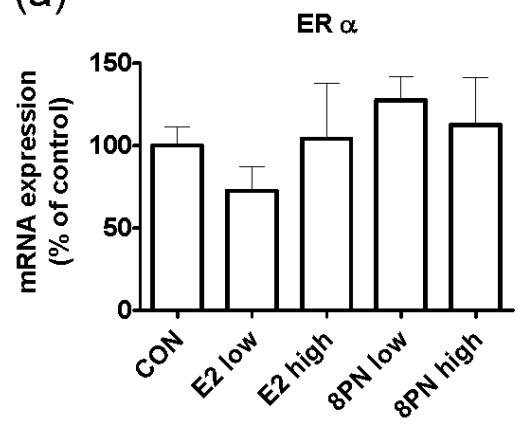

(b)

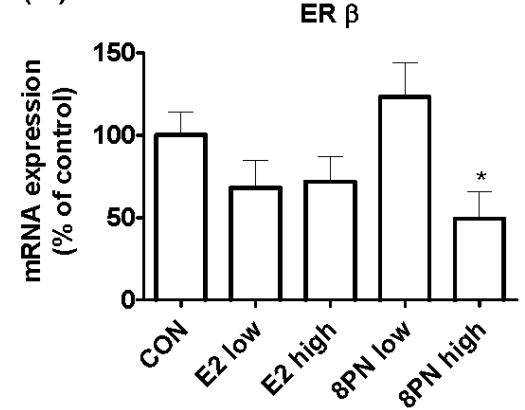

(c)

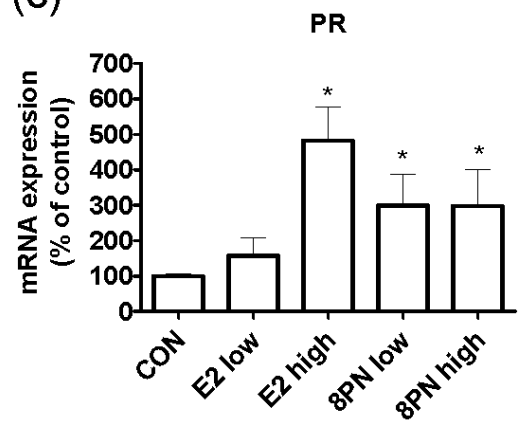

(d)

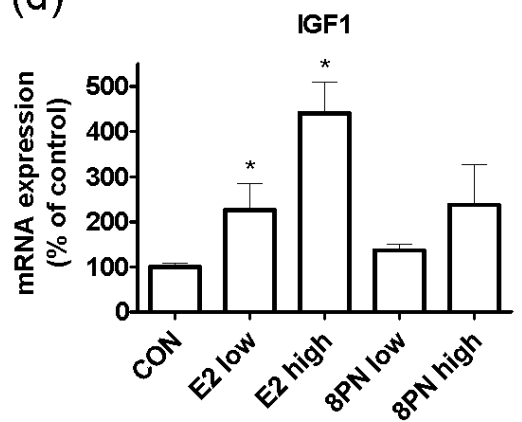

(e)

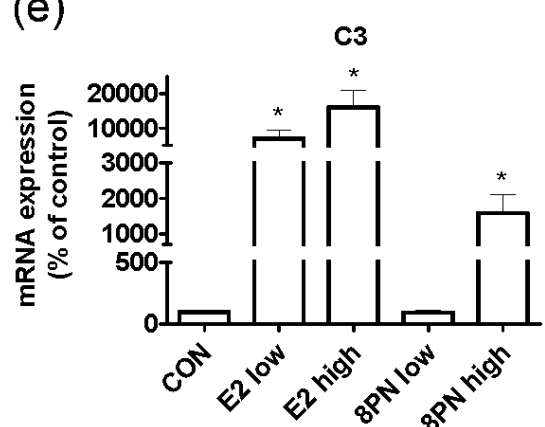

Figure 2 Effects of the two doses of E2 and 8PN on uterine ER $\alpha$ (a), ER $\beta$ (b), PR (c), IGF-I (d) and complement protein C3 (e) gene expression. Note significant effects of $8 \mathrm{PN}$ at the high dose on ER, $\mathrm{PR}$ and $\mathrm{C} 3$, which are similar to those exerted by $\mathrm{E} 2$. ${ }^{\star} \mathrm{P}<0 \cdot 05 \mathrm{vs}$ control.

uterotropic effects, as demonstrated by the unaffected weights in comparison to the ovx controls. Serum LH levels, however, were also unchanged and therefore - to extrapolate from the animal model - a beneficial effect on hot flushes appears unlikely.

The availability of highly sensitive molecular tools allows us to study more subtle effects. In an attempt to unravel more discrete effects of $8 \mathrm{PN}$ in the hypothalamus, pituitary and uterus, we studied expression of several genes known to be regulated by estrogens. The effects of $\mathrm{E} 2$ in the uterus are mediated by the ER $\alpha$, since Er $\alpha$, but not $\mathrm{ER} \beta$, knockout mice have no uterine response to estrogen (Couse \& Korach 1999). ER $\alpha$ was affected neither by E2B nor by 8PN, whereas ER $\beta$ gene expression was reduced by both doses of $\mathrm{E} 2 \mathrm{~B}$ and by the higher dose of $8 \mathrm{PN}$. Currently, the role of $\mathrm{ER} \beta$ in the uterus is unknown, as ER $\beta$-specific compounds are devoid of uterotropic effects (Seidlova-Wuttke et al. 2003a, Hillisch (a)

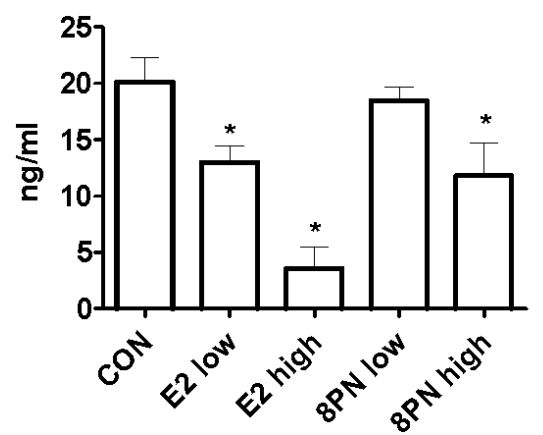

(b)

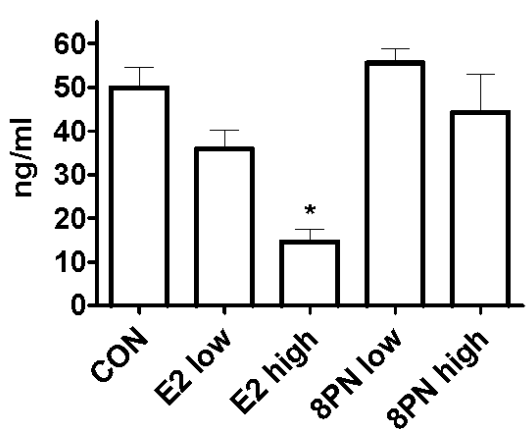

(c)

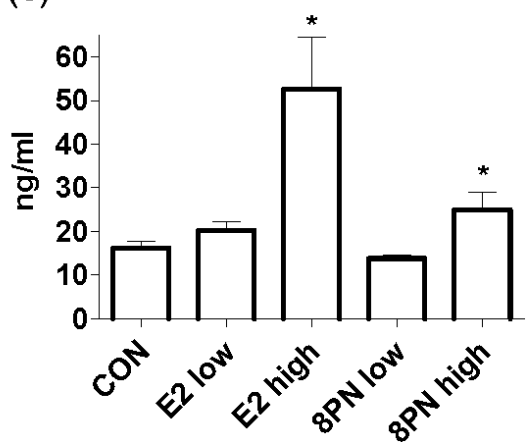

Figure 3 Effects of $\mathrm{E} 2$ and $8 \mathrm{PN}$ at two doses on serum $\mathrm{LH}$ (a), FSH (b) and prolactin (c). 8PN at the high dose mimicked the effects of E2. ${ }^{*} P<0 \cdot 05$ vs control. 
(a)

LH $\alpha$ Subunit

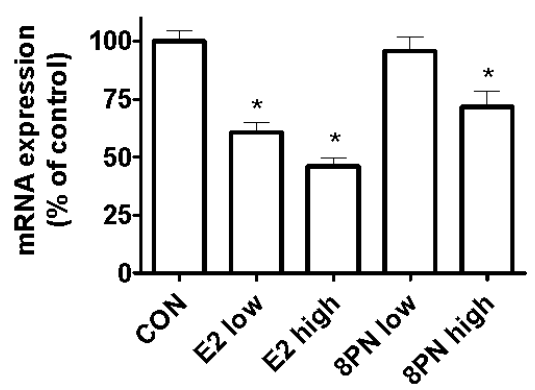

(c)

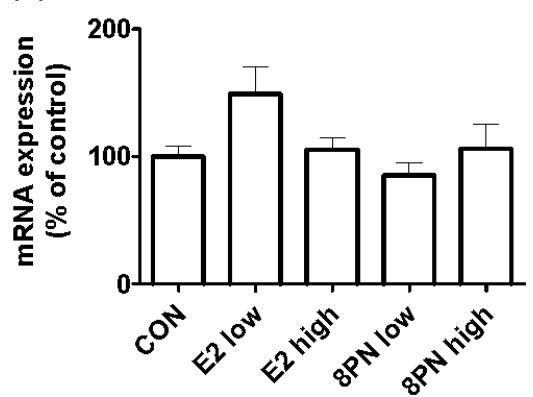

(b)

LH $\beta$ Subunit

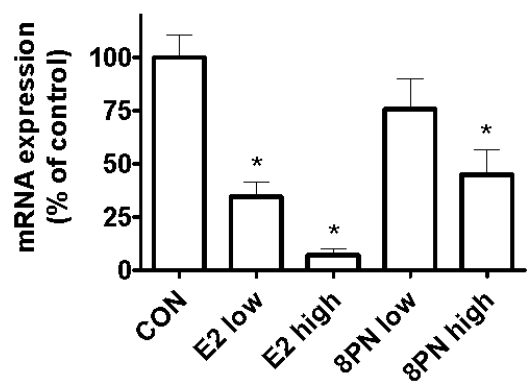

(d)

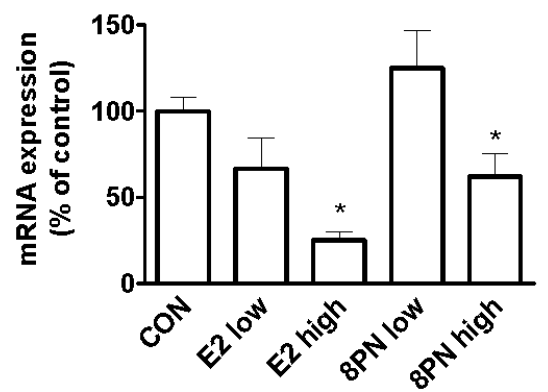

(e)

GnRH-R

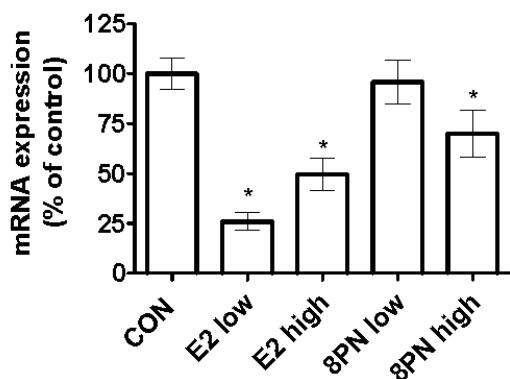

Figure 4 Effects of E2 and 8PN of two doses on the gene expression of pituitary LH $\alpha$ - and $\beta$-subunits (a and b), ER $\alpha$ and ER $\beta$ (c and d) and $\mathrm{GnRH}$ receptor (e). Note the significant effects of the high dose of $8 \mathrm{PN}$ and the LH subunits, ER $\beta$ and GnRH receptor, which were also seen in the E2-treated animals. ${ }^{*} P<0 \cdot 05$ vs control.

et al. 2004); hence, the effects of its downregulation by E2 and $8 \mathrm{PN}$ remain enigmatic. The upregulation of IGF-I by $\mathrm{E} 2$ and $8 \mathrm{PN}$ is a typical estrogenic effect, as IGF-I causes estrogen-induced proliferation of uterine tissue and prepares the endometrium for possible pregnancy (Fazleabas et al. 2004), and this response is specified by the high progesterone levels after ovulation (Fazleabas \& Strakova 2002). Therefore, increased PR expression is also necessary for maintenance of early pregnancy. It is known that the complement protein C3 is massively upregulated under estrogenic stimuli (Seidlova-Wuttke et al. 2004b), and this involves primarily an Er $\alpha$-mediated mechanism (Harris et al. 2002, Seidlova-Wuttke et al. 2003b). It was therefore not surprising to observe a strong upregulating effect of 8PN on $\mathrm{C} 3$ gene expression as well. Both doses of $\mathrm{E} 2 \mathrm{~B}$ and of $8 \mathrm{PN}$ were without effect on gene expression of GnRH in the POA, where most perikarya of these neurons are located in the rat (Gore 2002). Moreover, $\mathrm{GnRH}$ receptor gene expression in the $\mathrm{MBH}$, where these receptors are expressed (Piva et al. 2004), remained unchanged under any of the treatments. This indicates that the LH- and FSH-suppressive effects of E2B and 8PN do not result in changed $\mathrm{GnRH}$ production and receptor sensitivity within the hypothalamus, where $\mathrm{GnRH}$ is known to exert an 'ultrashort' loop feedback on its own secretion (Piva et al. 2004). Hence, the hypothalamic

Table 1 Effect of 2 doses of E2 (0.17 and $0.7 \mathrm{mg} /$ animal per day) and 8PN $(6.8$ and $68.4 \mathrm{mg} /$ animal per day) on mRNA of $E R \alpha, E R \beta, G n R H$ and $\mathrm{GnRH}$-receptor, given as \% of respective control (means \pm s.E.M.)

\begin{tabular}{|c|c|c|c|c|c|}
\hline & mRNA transcript & E2 low & E2 high & 8PN low & 8PN high \\
\hline \multicolumn{6}{|c|}{ Structure } \\
\hline \multirow[t]{3}{*}{ POA } & $\mathrm{ER} \alpha$ & $213 \cdot 9 \pm 62 \cdot 49$ & $147 \cdot 6 \pm 28 \cdot 51$ & $158 \cdot 1 \pm 38 \cdot 48$ & $157 \cdot 8 \pm 34 \cdot 58$ \\
\hline & $E R \beta$ & $164 \cdot 2 \pm 39 \cdot 38$ & $121 \cdot 5 \pm 16 \cdot 77$ & $120 \cdot 7 \pm 22 \cdot 48$ & $111 \cdot 4 \pm 16 \cdot 62$ \\
\hline & $\mathrm{GnRH}$ & $284 \cdot 8 \pm 176 \cdot 8$ & $294 \cdot 1 \pm 159 \cdot 2$ & $116 \cdot 2 \pm 29 \cdot 6$ & $52 \cdot 5 \pm 14 \cdot 65$ \\
\hline \multirow[t]{3}{*}{$\mathrm{MBH}$} & $\mathrm{ER} \alpha$ & $116 \cdot 2 \pm 39 \cdot 67$ & $87 \cdot 9 \pm 18 \cdot 45$ & $116 \cdot 2 \pm 16 \cdot 29$ & $111 \cdot 0 \pm 12 \cdot 22$ \\
\hline & $\mathrm{ER} \beta$ & $83 \cdot 3 \pm 15 \cdot 26$ & $84 \cdot 8 \pm 18 \cdot 08$ & $81 \cdot 0 \pm 7 \cdot 98$ & $106 \cdot 0 \pm 8 \cdot 23$ \\
\hline & GnRH-R & $591 \cdot 1 \pm 327 \cdot 8$ & $70 \cdot 57 \pm 18.68$ & $156 \cdot 2 \pm 65 \cdot 06$ & $122 \cdot 4 \pm 38 \cdot 4$ \\
\hline
\end{tabular}


mechanisms involved in the negative feedback of estrogens, which result in reduced serum LH levels, are due to other, not yet fully explored hypothalamic mechanisms.

The negative feedback effect of E2B on $\mathrm{LH}$ and FSH also involves a pituitary component which is in part shared by $8 \mathrm{PN}$. Both substances reduce $\mathrm{ER} \alpha, \mathrm{ER} \beta$ and $\mathrm{GnRH}$ receptor mRNA transcripts. Hence, synthesis of bioactive $\mathrm{LH}$ and FSH, as well as of the GnRH receptor, appears to be inhibited. Opposite effects were observed earlier under short-term application conditions of E2 (Quinones-Jenab et al. 1996, Shupnik 1996). Direct pituitary effects of 8PN were never reported, but, as in the uterus, this flavanone appears to act weakly, like E2, in the pituitary.

E2B significantly increased serum prolactin levels, and this effect was only marginally shared by the high dose of $8 \mathrm{PN}$. This is surprising, as $8 \mathrm{PN}$ shared the inhibitory effects of E2 on gonadotropin release. Possibly higher estrogenic power is needed to stimulate lactotrophs than is necessary to inhibit gonadotrophs.

In view of its relevance to human physiology, the serum concentration of $\mathrm{E} 2$ and $8 \mathrm{PN}$ deserve discussion. Beer, particularly strong ale, but also preparations marketed for bust enlargement, contain relatively high amounts of 8PN. Values of $4 \mathrm{mg} / \mathrm{l}$ beer and an identical amount of isoxanthohumol, which can be converted to $8 \mathrm{PN}$ by the intestinal flora, have been reported (Stevens et al. 1999, Possemiers et al. 2005). Hence, intake of high quantities $(\mathrm{mg})$ of $8 \mathrm{PN}$ is possible. Pharmacologists claim that doses per $\mathrm{kg} / \mathrm{BW}$ applied to rats must be 10-15-fold higher than in man in order to exert equipotent effects (Krasovskii 1976, Davidson et al. 1986, Vocci \& Farber 1988, Schneider et al. 2004). Hence, the dose used in the present experiments may well be of importance for human physiology and - in agreement with earlier reports (Milligan et al. 2000) - may have adverse effects in the uterus that require addition of a progestin to prevent endometrial hyperplasia and carcinoma (Lethaby et al. 2004). The low dose of E2 used in the present experiment can be considered physiologic for rats, as they are in the range seen in proestrus (Smith et al. 1975), whereas the higher dose is clearly supraphysiologic.

Altogether, the effects of $\mathrm{E} 2 \mathrm{~B}$ and $8 \mathrm{PN}$ in the hypothalamo/pituitary axis appear to be very similar, and therefore it is highly likely that $8 \mathrm{PN}$ will be effective, although less potent, in reducing climacteric complaints, particularly hot flushes, of which the occurrence is closely coupled to the activity of the GnRH pulse generator. As in the hypothalamo/pituitary axis, 8PN at the low dose had no effect on uterine weight, PR, IGF-I or C3 mRNA transcripts. At the high dose, however, these parameters were stimulated, and only at these doses was $8 \mathrm{PN}$ inhibitory in the hypothalamo/pituitary axis. Therefore, the ovx rat model suggests that $8 \mathrm{PN}$ at doses that affect the GnRH pulse generator would also be effective in the uterus. If this is confirmed in menopausal women, the compound can probably not be used in hormone replacement therapy without counteracting progestins in any therapeutic scheme.

\section{Acknowledgements}

We thank Schering AG (Dr Michael Hümpel), Berlin, Germany, for providing the whole amount of 8PN required to conduct this long-term experiment. The supply of RIA reagents by the National Hormone and Pituitary Program of the NIH (Dr A F Parlow, Harbor General Hospital, Torrance, CA, USA) is gratefully acknowledged. Technical support was provided by Maria Metten (RIA and binding assays), Claudia Neitzel (brain punches/PCR) and Annette Witt (PCR).

\section{Funding}

This work was supported by the European Commission (EURISKED contract no. EVK1-CT2002-00128). The authors declare that there is no conflict of interest that would prejudice the impartiality of this scientific work.

\section{References}

Bovee TF, Helsdingen RJ, Rietjens IM, Keijer J \& Hoogenboom RL 2004 Rapid yeast estrogen bioassays stably expressing human estrogen receptors alpha and beta, and green fluorescent protein: a comparison of different compounds with both receptor types. Journal of Steroid Biochemistry and Molecular Biology 91 99-109.

Chin WW, Godine JE, Klein DR, Chang AS, Tan LK \& Habener JF 1983 Nucleotide sequence of the cDNA encoding the precursor of the beta subunit of rat lutropin. PNAS 80 4649-4653.

Coldham NG \& Sauer MJ 2001 Identification, quantitation and biological activity of phytoestrogens in a dietary supplement for breast enhancement. Food Chemistry and Toxicology 39 1211-1224.

Couse JF \& Korach KS 1999 Estrogen receptor null mice: what have we learned and where will they lead us? Endocrine Reviews 20 358-417.

Davidson IW, Parker JC \& Beliles RP 1986 Biological basis for extrapolation across mammalian species. Regulatory Toxicology and Pharmacology 6 211-237.

Diel P, Thomae RB, Caldarelli A, Zierau O, Kolba S, Schmidt S, Schwab P, Metz P \& Vollmer G 2004 Regulation of gene expression by 8 -prenylnaringenin in uterus and liver of Wistar rats. Planta Medica 70 39-44.

Fazleabas AT \& Strakova Z 2002 Endometrial function: cell specific changes in the uterine environment. Molecular and Cellular Endocrinology 186 143-147.

Fazleabas AT, Kim JJ \& Strakova Z 2004 Implantation: embryonic signals and the modulation of the uterine environment - a review. Placenta 25 Suppl A S26-S31.

Feeley KM \& Wells M 2001 Hormone replacement therapy and the endometrium. Journal of Clinical Pathology 54 435-440.

Fugh-Berman A 2003 'Bust enhancing' herbal products. Obstetics and Gynecology 101 1345-1349.

Gambone J, Meldrum DR, Laufer L, Chang RJ, Lu JK \& Judd HL 1984 Further delineation of hypothalamic dysfunction responsible for menopausal hot flashes. Journal of Clinical Endocrinology and Metabolism 59 1097-1102. 
Godine JE, Chin WW \& Habener JF 1982 alpha Subunit of rat pituitary glycoprotein hormones. Primary structure of the precursor determined from the nucleotide sequence of cloned cDNAs. Journal of Biological Chemistry 257 8368-8371.

Gore AC 2002 Gonadotropin-releasing hormone (GnRH) neurons: gene expression and neuroanatomical studies. Progress in Brain Research 141 193-208.

Harris HA, Katzenellenbogen JA \& Katzenellenbogen BS 2002 Characterization of the biological roles of the estrogen receptors, ERalpha and ERbeta, in estrogen target tissues in vivo through the use of an ERalpha-selective ligand. Endocrinology 143 4172-4177.

Hillisch A, Peters O, Kosemund D, Muller G, Walter A, Schneider B, Reddersen G, Elger W \& Fritzemeier KH 2004 Dissecting physiological roles of estrogen receptor alpha and beta with potent selective ligands from structure-based design. Molecular Endocrinology 18 1599-1609.

Jarry H, Sprenger M \& Wuttke W 1986 Rates of release of GABA and catecholamines in the mediobasal hypothalamus of ovariectomized and ovariectomized estrogen-treated rats: correlation with blood prolactin levels. Neuroendocrinology 44 422-428.

Jarry H, Leonhardt S \& Wuttke W 1990 A norepinephrine-dependent mechanism in the preoptic/anterior hypothalamic area but not in the mediobasal hypothalamus is involved in the regulation of the gonadotropin-releasing hormone pulse generator in ovariectomized rats. Neuroendocrinology $\mathbf{5 1} 337-344$.

Kitaoka M, Kadokawa H, Sugano M, Ichikawa K, Taki M, Takaishi S, Iijima Y, Tsutsumi S, Boriboon M \& Akiyama T 1998 Prenylflavonoids: a new class of non-steroidal phytoestrogen. I. Isolation of 8-isopentenylnaringenin and an initial study on its structure-activity relationship. Planta Medica 64 511-515.

Krasovskii GN 1976 Extrapolation of experimental data from animals to man. Environmental Health Perspectives 13 51-58.

Lethaby A, Suckling J, Barlow D, Farquhar CM, Jepson RG \& Roberts H 2004 Hormone replacement therapy in postmenopausal women: endometrial hyperplasia and irregular bleeding. Cochrane Database System Review CD000402.

Mallis LM, Sarkahian AB, Harris HA, Zhang MY \& McConnell OJ 2003 Determination of rat oral bioavailability of soy-derived phytoestrogens using an automated on-column extraction procedure and electrospray tandem mass spectrometry. Journal of Chromatography. B. Analytical Technologies in the Biomedical and Life Sciences 796 71-86.

Milligan SR, Kalita JC, Heyerick A, Rong H, De Cooman L \& De Keukeleire D 1999 Identification of a potent phytoestrogen in hops (Humulus lupulus L.) and beer. Journal of Clinical Endocrinology and Metabolism 84 2249-2252.

Milligan SR, Kalita JC, Pocock V, Van De Kauter V, Stevens JF, Deinzer ML, Rong H \& De Keukeleire D 2000 The endocrine activities of 8-prenylnaringenin and related hop (Humulus lupulus L.) flavonoids. Journal of Clinical Endocrinology and Metabolism 85 4912-4915.

Milligan S, Kalita J, Pocock V, Heyerick A, De Cooman L, Rong H \& De Keukeleire D 2002 Oestrogenic activity of the hop phyto-oestrogen, 8-prenylnaringenin. Reproduction 123 235-242.

Miyamoto M, Matsushita Y, Kiyokawa A, Fukuda C, Iijima Y, Sugano M \& Akiyama T 1998 Prenylflavonoids: a new class of non-steroidal phytoestrogen. II. Estrogenic effects of 8-isopentenylnaringenin on bone metabolism. Planta Medica 64 516-519.

Pepper MS, Hazel SJ, Humpel M \& Schleuning WD 2004 8-prenylnaringenin, a novel phytoestrogen, inhibits angiogenesis in vitro and in vivo. Journal of Cell Physiology 199 98-107.

Petersen SL, Ottem EN \& Carpenter CD 2003 Direct and indirect regulation of gonadotropin-releasing hormone neurons by estradiol. Biology of Reproduction 69 1771-1778.
Piva F, Zanisi M, Motta M \& Martini L 2004 'Ultrashort' control of hypothalamic hormones secretion: a brief history. Journal of Endocrinological Investigations 27 68-72.

Possemiers S, Heyerick A, Robbens V, De Keukeleire D \& Verstraete W 2005 Activation of proestrogens from hops (Humulus lupulus L.) by intestinal microbiota; conversion of isoxanthohumol into 8-prenylnaringenin. Journal of Agriculture and Food Chemistry 53 6281-6288.

Quinones-Jenab V, Jenab S, Ogawa S, Funabashi T, Weesner GD \& Pfaff DW 1996 Estrogen regulation of gonadotropin-releasing hormone receptor messenger RNA in female rat pituitary tissue. Brain Research. Molecular Brain Research 38 243-250.

Rossouw JE, Anderson GL, Prentice RL, LaCroix AZ, Kooperberg C, Stefanick ML, Jackson RD, Beresford SA, Howard BV, Johnson KC et al. 2002 Risks and benefits of estrogen plus progestin in healthy postmenopausal women: principal results from the Women's Health Initiative randomized controlled trial. Journal of the American Medical Association 288 321-333.

Roth C, Schmidberger H, Lakomek M, Witt O, Wuttke W \& Jarry H 2001 a Reduction of gamma-aminobutyric acid-ergic neurotransmission as a putative mechanism of radiation induced activation of the gonadotropin releasing-hormone-pulse generator leading to precocious puberty in female rats. Neuroscience Letters $29745-48$.

Roth C, Schricker M, Lakomek M, Strege A, Heiden I, Luft H, Munzel U, Wuttke W \& Jarry H 2001 b Autoregulation of the gonadotropin-releasing hormone $(\mathrm{GnRH})$ system during puberty: effects of antagonistic versus agonistic GnRH analogs in a female rat model. Journal of Endocrinology 169 361-371.

Schleicher F, Tauber U, Louton T \& Schunack W 1998 Tissue distribution of sex steroids: concentration of 17 beta-oestradiol and cyproterone acetate in selected organs of female Wistar rats. Pharmacology and Toxicology 82 34-39.

Schneider K, Oltmanns J \& Hassauer M 2004 Allometric principles for interspecies extrapolation in toxicological risk assessment empirical investigations. Regulations in Toxicology and Pharmacology 39 334-347.

Seidlova-Wuttke D, Becker T, Christoffel V, Jarry H \& Wuttke W $2003 a$ Silymarin is a selective estrogen receptor beta (ERbeta) agonist and has estrogenic effects in the metaphysis of the femur but no or antiestrogenic effects in the uterus of ovariectomized (ovx) rats. Journal of Steroid Biochemistry and Molecular Biology 86 179-188.

Seidlova-Wuttke D, Jarry H, Becker T, Christoffel V \& Wuttke W 2003 b Pharmacology of Cimicifuga racemosa extract BNO 1055 in rats: bone, fat and uterus. Maturitas 44 Suppl 1 S39-S50.

Seidlova-Wuttke D, Hesse O, Jarry H, Christoffel V, Spengler B, Becker T \& Wuttke W 2003c Evidence for selective estrogen receptor modulator activity in a black cohosh (Cimicifuga racemosa) extract: comparison with estradiol-17 beta. European Journal of Endocrinology 149 351-362.

Seidlova-Wuttke D, Jarry H \& Wuttke W 2004a Pure estrogenic effect of benzophenone-2 (BP2) but not of bisphenol A (BPA) and dibutylphtalate (DBP) in uterus, vagina and bone. Toxicology 205 103-112.

Seidlova-Wuttke D, Hesse O, Jarry H, Rimoldi G, Thelen P, Christoffel V \& Wuttke W 2004 b Belamcanda chinensis and the thereof purified tectorigenin have selective estrogen receptor modulator activities. Phytomedicine 11 392-403.

Shughrue PJ, Dellovade TL \& Merchenthaler I 2002 Estrogen modulates oxytocin gene expression in regions of the rat supraoptic and paraventricular nuclei that contain estrogen receptor-beta. Progress in Brain Research 139 15-29.

Shupnik MA 1996 Gonadotropin gene modulation by steroids and gonadotropin-releasing hormone. Biology of Reproduction 54 279-286.

Smith MS, Freeman ME \& Neill JD 1975 The control of progesterone secretion during the estrous cycle and early 
pseudopregnancy in the rat: prolactin, gonadotropin and steroid levels associated with rescue of the corpus luteum of pseudopregnancy. Endocrinology 96 219-226.

Stevens JF, Taylor AW \& Deinzer ML 1999 Quantitative analysis of xanthohumol and related prenylflavonoids in hops and beer by liquid chromatography-tandem mass spectrometry. Journal of Chromatography A 832 97-107.

Tataryn IV, Meldrum DR, Lu KH, Frumar AM \& Judd HL 1979 LH, FSH and skin temperature during the menopausal hot flash. Journal of Clinical Endocrinology and Metabolism 49 152-154.

Vocci F \& Farber T 1988 Extrapolation of animal toxicity data to man. Regulations in Toxicology and Pharmacology 8 389-398.
Zierau O, Gester S, Schwab P, Metz P, Kolba S, Wulf M \& Vollmer G 2002 Estrogenic activity of the phytoestrogens naringenin, 6-(1,1-dimethylallyl)naringenin and 8-prenylnaringenin. Planta Medica 68 449-451.

Zierau O, Morrissey C, Watson RW, Schwab P, Kolba S, Metz P \& Vollmer G 2003 Antiandrogenic activity of the phytoestrogens naringenin, 6-(1,1-dimethylallyl)naringenin and 8-prenylnaringenin. Planta Medica 69 856-858.

Received 5 September 2005

Accepted 29 November 2005 